\title{
ASSESSMENT OF MODELS TO PREDICT SURFACE SUBSIDENCE IN THE CZECH PART OF THE UPPER SILESIAN COAL BASIN - CASE STUDY
}

\author{
Eva JIRÁNKOVÁ ${ }^{1)}$ *, Petr WACLAWIK ${ }^{1)}$ and Jan NEMCIK ${ }^{2)}$
}

\author{
${ }^{1)}$ Institute of Geonics of the Czech Academy of Sciences, Studentska 1768, 70800 Ostrava, Czech Republic \\ ${ }^{2}$ ) School of Civil, Mining and Environmental Engineering, University of Wollongong, Australia
}

*Corresponding author's e-mail: eva.jirankova@ugn.cas.cz

\section{ARTICLE INFO}

Article history:

Received 10 September 2020

Accepted 19 November 2020

Available online 25 November 2020

Keywords:

Longwall mining

Surface subsidence

Great depth

Finite element method

Knothe method

\begin{abstract}
This case study presents the verification of two surface subsidence prediction models for longwall mining at depths greater than $400 \mathrm{~m}$. The surface subsidence points were surveyed and compared for both models. The first model uses empirical calculations to predict the surface subsidence. This method is reliable for predicting surface subsidence at shallower depths. At present, however, coal mining has progressed to great depths. The second model is the 2-dimensional finite element method to predict surface subsidence. In contrast to the first method, this method is based on the regional parameters and uses the rock mass properties to evaluate surface subsidence for multiseams at any depth. Results show that the finite element method gives a better approximation of the measured surface subsidence than the Knothe method. The maximum surface subsidence, which was determined by the FEM method, was used to adjust the extraction coefficient in the Knothe's method. The predicted value differs from the measured value by $8 \%$. The slope of the predicted subsidence trough was within the range of $2-8 \%$ from the surveyed subsidence. This case study proposes a procedure for using both models to successfully predict the surface subsidence.
\end{abstract}

\section{INTRODUCTION}

Surface subsidence due to mining is a wellrecognised problem in many countries. It is important to understand the mechanisms that lead to surface subsidence. The movements of overlying layers, hence also the movements of the ground surface, depend on many factors, which include the mechanical properties of overlying and surrounding rocks, the geological structure, the degree of tectonic fracturing, the deformation of rocks due to previous mining activity, the thickness of the extracted seam, the depth of extraction, the method of mining (e.g. total extraction mining, longwall mining or cave mining methods), geometry of the mined-out area, and speed of mining advance, among others (Jiránková, 2012; Jiang et al., 2020).

The surface subsidence prediction using the Knothe's method is well known (Knothe, 1984). The method is based on the principle of superposition and is closely connected to the definition of the main influence range. The radius of the main influence range also gradually increases with mining at great depths. Theoretically, it is assumed that with an increasing radius of the main influence range (and hence the mining depth), the subsidence trough will be larger, more flat, shallower and with less steep slopes in the subsidence trough. The FEM method, which is based on the 2D elasto-plastic finite element stress analysis program, is extensively used for modelling stress fields and deformation around excavations (Małkowski, 2015) as well as surface subsidence modelling at shallow depths (Tajduś, 2009). The Probability Integral Method based on a normal distribution can be also used for the surface subsidence prediction. The calculation model for surface subsidence using a Cauchy distribution provides a universal method for the calculation of surface subsidence (Jiang et al., 2020).

Based on experience, the traditional empirical subsidence model is used in the Czech part of the Upper Silesian Coal Basin (USCB). This subsidence model is dependent on the angle value of the main influence range $(\beta)$, defined as $\beta=90^{\circ}-\theta$, where $\theta$ is the angle of draw (Cui et al., 2013; Ren and Li, 2008), as shown in Figure 1. Using the main angle of influence, the model can predict the extent of mining influence on the surface subsidence. By increasing the angle of main influence, the subsidence trough will be less extensive but the surface deformations will be larger. When reducing the angle of main influence, the subsidence trough will be more extensive but the surface deformations will be smaller. Mining 


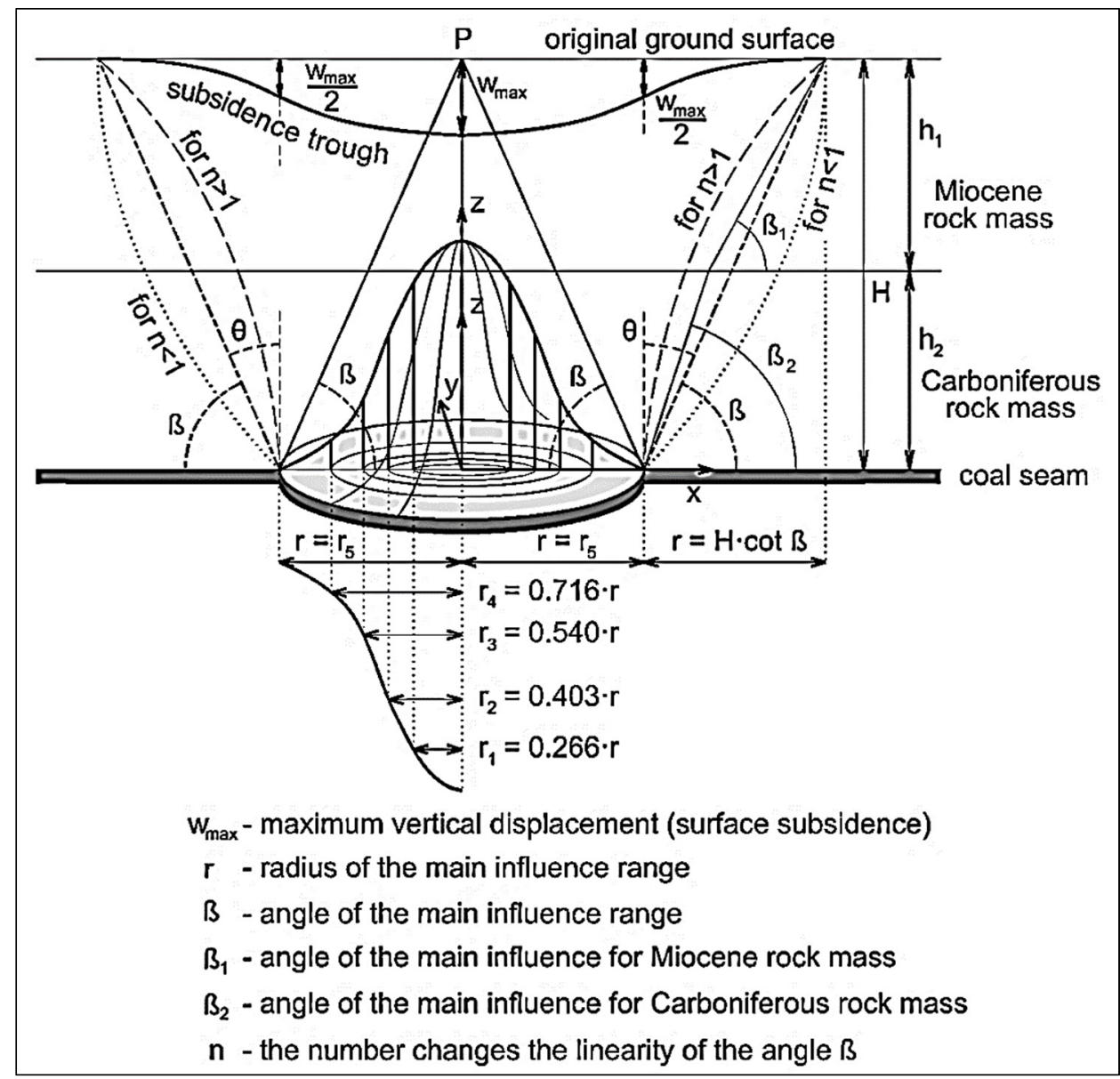

Fig. 1 Illustration of subsidence parameters and distribution of main influence range according to Knothe (Knothe, 1984; Sroka et al., 2015; Tajduś et al., 2018).

exploitation effects in the rock mass are also used in the form of main influence (Sroka et al., 2015; Tajduś et al., 2018), depending on the number $n$, where the number $\mathrm{n}$ changes the linearity of the angle $\beta$ and represents the influence of the area factor in the rock mass, determined by the angle of the main influence for Miocene rocks $\left(\beta_{1}\right)$, for Carboniferous rocks $\left(\beta_{2}\right)$ and the thickness of the Miocene rocks $\left(h_{1}\right)$ and Carboniferous rocks $\left(h_{2}\right)$ as can be seen in Figure 1. The angle of main influence is also an important parameter for determining the full effective area. Geometrically, the full effective area is the base of a cone whose height is the depth of mining $(H)$, the vertex lies on the surface point $(P)$, and the surface line forms an angle of the main influence with the vertex. The radius of the main influence range $(r)$ is determined by the depth of extraction and the angle of main influence.

The 'effective' seam excavation is also known as the critical width area needed to produce the maximum surface subsidence $\left(w_{\max }\right)$ and can be represented in 3 - dimensions as the top of the cone, see Figure 1.

Prediction using the empirical subsidence model depends on the choice of the extraction coefficient $(a)$ and the efficiency factor $(e)$ (Neset, 1984). However, with an increase in mining depth, the (natural and mining) technical conditions in which the method has been successfully used, is found to be change. Although the values ( $a$ and $e$ ) of the above-mentioned factors are being constantly verified, the difference between the measured and empirical subsidence, especially on slopes of subsidence troughs, increases. The Czech part of the USCB is fractured by a system of tectonic disturbances in the North-South and East- West directions. From an operational point of view, the system of tectonic disturbances manifests itself in the widths and lengths of the mined panels. The extracted area usually consists of several panels defining the main area of the influence range. The principle of the empirical subsidence model is explained below. Prediction using this empirical subsidence model is less reliable because of its inability to include the character of the rock mass in the model and changes in its properties due to previous mine workings. Our goal is to prove the suitability of using the finite element method and improve the predictions of surface subsidence in the complicated technical conditions (both natural and mining) in the Ostrava-Karvina Coalfield (OKC) in the Czech part of the USCB. 
Similar research is under way in Poland addressing subsidence prediction in the Polish part of the Upper Silesian Coal Basin. A comparison between the results obtained from the FEM numerical models and the results obtained from Knothe theory was successful (Tajduś, 2009). The parameters for Knothe's method were obtained for the observed region in the "Siersza" coal mine. The angle of main influence was determined as $54.46^{\circ}$ and the extraction coefficient of the method for filling the voids was 0.42 (caved with backfilling). The value of the elastic modulus in the fractured zone was $0.580 \mathrm{GPa}$. However, the comparison was only carried out for a depth of 325 to $330 \mathrm{~m}$. This is a shallow mining depth when considering the much deeper mining in the Czech part of the USCB.

The interface between "shallow" and "great" depths of mining can be described from two points of view. The first is the size of the excavated area and the second is the rate of the overlying strata failure. In the case of shallow mining depths, the main influence range is already excavated with one (or a maximum of two) widths of longwall mining. If the average of one longwall mining width is $200 \mathrm{~m}$ and the angle of the main influence is $62^{\circ}$, then the shallow mining depth reaches $400 \mathrm{~m}$ in the conditions in the Upper Silesian Coal Basin. Failure of the overlying strata regularly occurs without the effects of difficult geomechanical conditions at these mining depths, which is also related to the character of the rock mass in the particular locality (Ptacek et al., 2017). That is the reason why it is impossible to specify a generalised value for the world's different coalfields.

This paper evaluates the surface subsidence caused by longwall mining of the seams 38, 39 and 40 in Lazy Mine. In the specific conditions of the Lazy Mine, the average mining depth ranges from 619 to $694 \mathrm{~m}$ and the continuity of the measured data on surface subsidence was maintained for eighteen years (between 1997 and 2015). This makes it possible to follow up the effect of growing depth in the results of modelled surface subsidence. Comparisons of measured and modelled surface subsidence clearly show the problems of predicting surface subsidence as the depth of mining increases. The empirical method
(Knothe's method) and the numerical modelling method (FEM) were used to determine surface subsidence. In general, empirical methods are suitable for geometrically simple areas, but their disadvantage (compared to FEM) is the inability to model mining conditions using different types of materials. This case study presents how the FEM method can be used to predict surface subsidence when mining at great depths. The main task was to solve how to use the method, based on elasto-plastic stress analysis, to approximate the real rock mass conditions which comprise both elastic-plastic deformation and brittle deformation.

\section{STUDY AREA}

The Lazy Mine is part of the Ostrava-Karvina Coalfield in the Czech Republic. It is the largest deep mining complex in the Czech Republic and is part of the Upper Silesian Coal Basin. The Lazy Mine is divided into nine mining blocks and is currently extracting coal from the Saddle Members of the Karvina Formation. There are layers of black coal seams up to $6 \mathrm{~m}$ thick and the rock mass mainly consists of sandstones and conglomerates. The Lazy Mine extraction in this area uses the longwall mining method with controlled caving. The research studies (Konicek et al., 2013; Konicek et al., 2019; Konicek et al., 2018; Jiránková et al., 2012) proved that the rock mass has anisotropic properties and mining is accompanied by significant seismological phenomena.

Jiránková (2010) describes the progress in mining seams 38, 39 and 40 from 1997 to 2009, including the effects of mining on forming the subsidence trough. Subsequently, longwall mining seam 40 was excavated until 2013, as described in Figure 2. This figure also shows two surface section lines. The curved line represents the levelled surface points from 1 to 30 , while the section $\mathrm{A}-\mathrm{A}^{\prime}$ represents the adjusted surface subsidence in the straight line used in the numerical model. Details of the technical data from the extracted seams 38,39 and 40 (in section line $\mathrm{A}-\mathrm{A}^{\prime}$ ) are given in Table 1 . The geometry and depth of the coal seams are shown in Figure 6.

Table 1 Technical data from the extracted seams 38, 39 and 40 in the section line $\mathrm{A}-\mathrm{A}^{\prime}$.

\begin{tabular}{lccc}
\hline & Seam 38 & Seam 39 & Seam 40 \\
\hline Average mining depth & $619 \mathrm{~m}$ & $634 \mathrm{~m}$ & $694 \mathrm{~m}$ \\
Beginning of mining & 1.6 .1997 & 1.11 .2003 & 1.11 .2006 \\
End of mining & 10.4 .2003 & 28.1 .2008 & 1.2 .2013 \\
Extracted seam thickness & $4.55-5.65 \mathrm{~m}$ & $4.10-5.80 \mathrm{~m}$ & $3.40-4.20 \mathrm{~m}$ \\
Carboniferous rock mass - thickness & $435 \mathrm{~m}$ & $450 \mathrm{~m}$ & $510 \mathrm{~m}$ \\
Miocene rock mass - thickness & $184 \mathrm{~m}$ & $184 \mathrm{~m}$ & $184 \mathrm{~m}$ \\
Average angle of main influence & $62.0^{\circ}$ & $62.1^{\circ}$ & $62.3^{\circ}$ \\
Average radius of main influence range (m) & $329 \mathrm{~m}$ & $336 \mathrm{~m}$ & $364 \mathrm{~m}$ \\
\hline
\end{tabular}



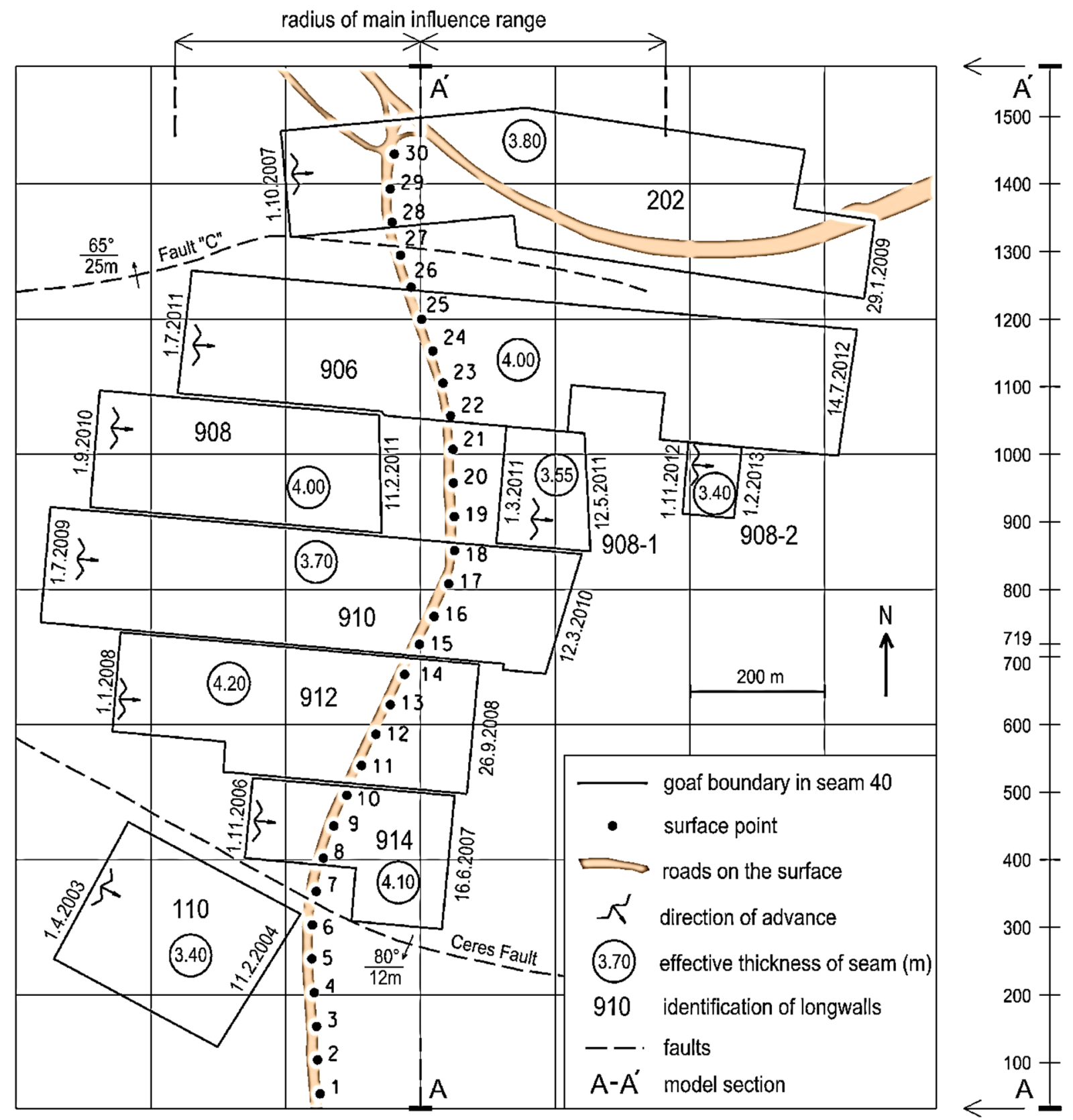

Fig. 2 Illustration of mining seam 40 in the $9^{\text {th }}$ block of the Lazy Mine, and longwalls $202,110$.

\subsection{MEASURED SUBSIDENCE}

The observed subsidence was determined from the levelling surveys using the DNA03 instrument with invar levelling rods (length of $3 \mathrm{~m}$ ) and a standard deviation of $0.3 \mathrm{~mm}$ per $\mathrm{km}$. The surface points were established using permanent survey marks. These marks were spaced at approximately $50 \mathrm{~m}$ intervals, as shown in Figure 2. The surface point heights were levelled two times a year (Jiránková, 2010). The accuracy of the surface point levelling was determined every time from two independent measurements taken as part of the routine survey. The root means square errors (RMSE) of the individual measurements ranged from 1.3 to $2.0 \mathrm{~mm}$. The mean subsidence error was determined with respect to the principle of the law of accumulation of errors. The mean error values of the subsidence were determined as the difference between the individual measurements and the initial measurement, with errors ranging between 1.9 and $2.4 \mathrm{~mm}$. A double value of this error was used to determine the $95 \%$ confidence level. All of the measured subsidence mentioned in this paper far exceeds the confidence level and thus the vertical displacements are proven with $5 \%$ risk. From the large set of measured data (Tichavský et al., 2020), the subsidence information was selected only for the dates 14.10.2003, 24.10.2012 and 26.9.2015, as indicated in Figure 3. 


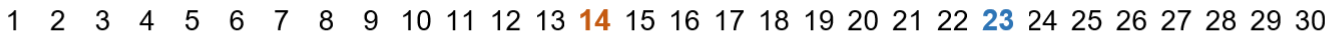

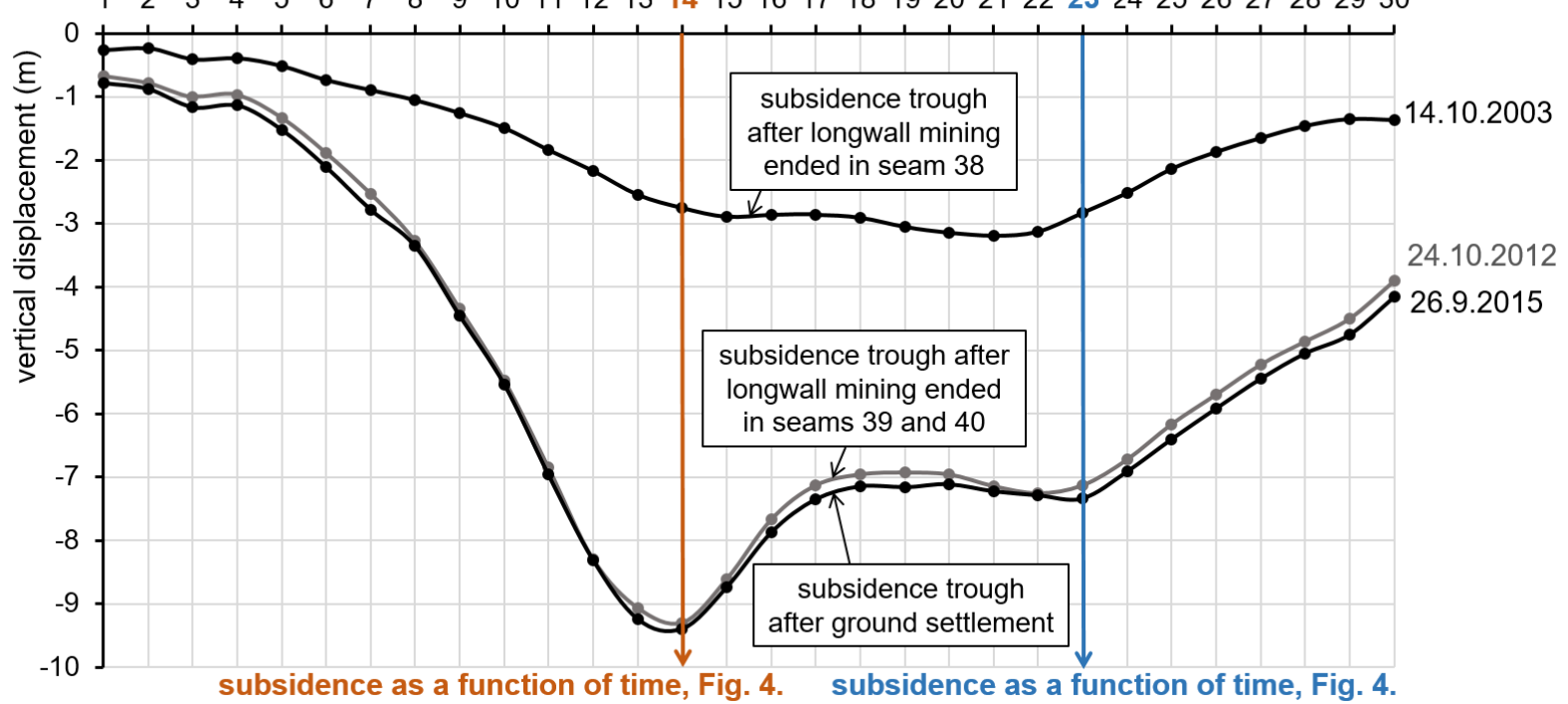

Fig. 3 Formation of a subsidence trough based on regular levelling of surface points.

time line (years)

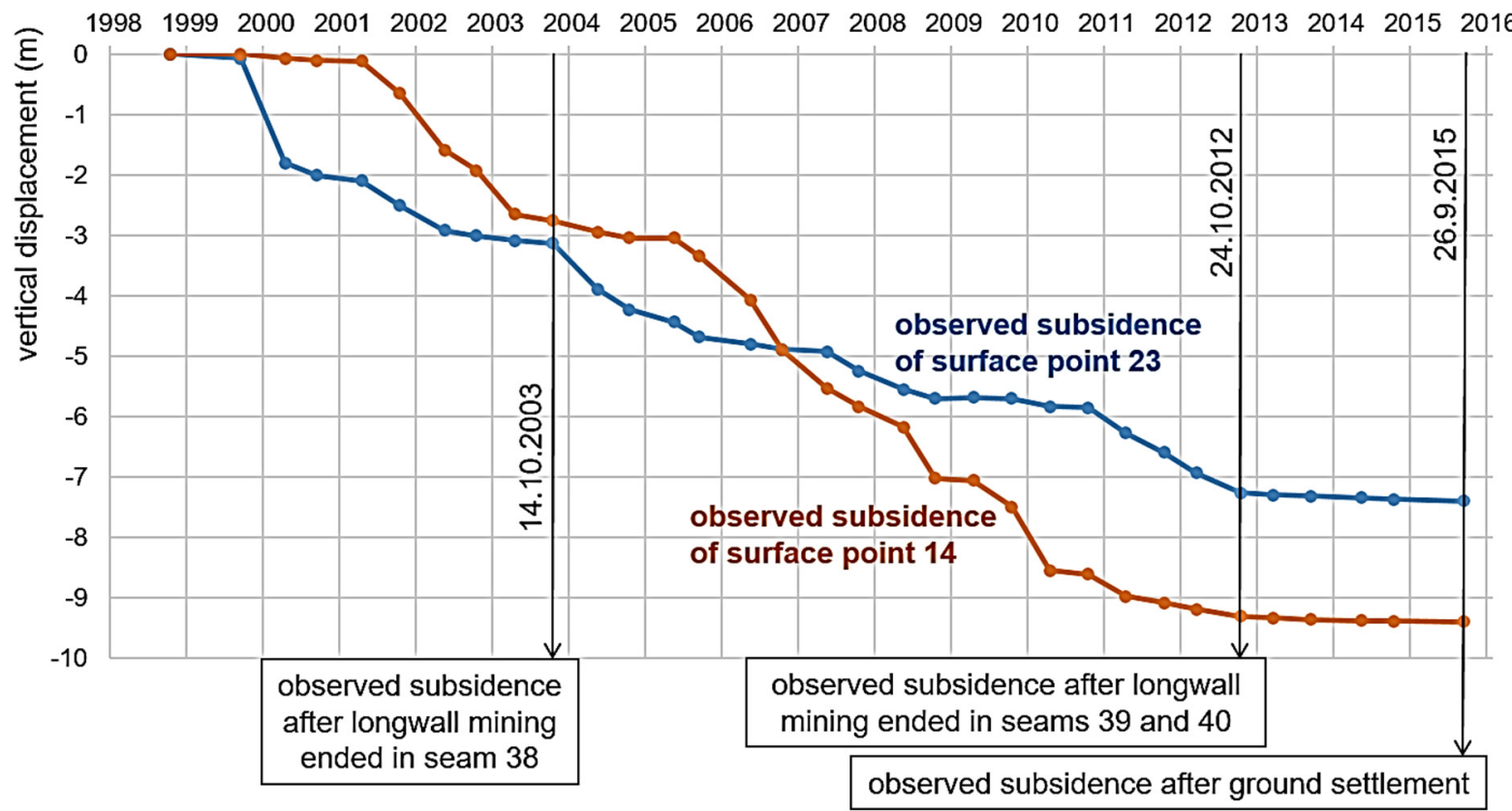

Fig. 4 Variation of observed subsidence as a function of time for surface points 14 and 23.

The first survey was carried out on 19.10.1998, when mining of the main part of the longwall 138906 was already in progress, so some of the initial subsidence, estimated to be negligible, was not measured. This fact was considered in the numerical model design. The second survey (in September 1999) was taken during mining of the subsequent panel in seam 38 at the time when $130 \mathrm{~m}$ was mined out. The measured surface subsidence was not more than $0.105 \mathrm{~m}$ different in both surveys. Surface subsidence of up to $1.803 \mathrm{~m}$ was observed on the third survey (in April 2000) after the direction mining of $500 \mathrm{~m}$ was mined out. The vertical displacements of the two surface points are shown in detail in Figure 4. The initial vertical displacement of surface point 23 occurred between October 1998 and September 1999 with a value of $0.075 \mathrm{~m}$. The main period of subsidence occurred between September 1999 and October 2012, with vertical displacement of $7.188 \mathrm{~m}$ followed by the stabilisation of surface subsidence 
over almost three years. The last measurement of surface subsidence was performed in September 2015, with the total vertical displacement of $7.400 \mathrm{~m}$ at surface point 23. The initial vertical displacement of surface point 14 occurred between October 1998 and April 2001 with a value of $0.120 \mathrm{~m}$. The main period of subsidence occurred between April 2001 and October 2012, with vertical displacement of $9.183 \mathrm{~m}$. The total vertical displacement of $9.394 \mathrm{~m}$ occurred at surface point 14 (in October 2015).

The surface points levelled on 14.10.2003 were determined after longwall mining ended in seam 38 and before mining began in the underlying seams. These specific, measured results were compared with the model predictions of surface subsidence due to excavation in seam 38. Since seams 39 and 40 were mined simultaneously, it was not possible to determine the subsidence due to each seam. Therefore the total measured subsidence due to the excavation of both seams was used, as measured on 24.10.2012 after the mining was completed. The last measurement of the surface levels was completed on 26.5.2015. Comparison of the two last measurements indicated a small difference due to ground settlement, as shown in Figure 3. The value of the difference was ranged from 11 to $248 \mathrm{~mm}$.

\section{METHODS}

\subsection{EMPIRICAL SUBSIDENCE MODEL}

The surface point due to mining performs a very complicated spatial movement. Subsidence is the vertical component of the surface point, resulting from displacement. The empirical calculation depends on the appropriate selection of individual parameters (Neset, 1984): the coefficient of extraction $(a)$, the coefficient of efficiency $(e)$ and the time coefficient $\left(\varphi_{t}\right)$. The empirical value of dynamic surface subsidence (time-dependent subsidence) is given by

$W_{t}=g \cdot a \cdot e \cdot \varphi_{t}$

Where $g$ is the thickness of mined-out areas and it represents a directly measured variable; its values are given in mining base maps. In the case of planned mining, the extraction thickness is determined by the project.

The extraction coefficient expresses the effect of the mining method, the efficiency coefficient expresses the dependence of the surface points' movement on the goaf size and the time coefficient expresses the time-dependent effect on the surface subsidence. The details of the coefficients are given in the following sections.

\subsubsection{EXTRACTION COEFFICIENT}

In mining engineering, the value of the extraction coefficient $(a)$ is chosen in the empirical calculation according to the mining method used. The range of values (a) recommended for the choice of the extraction coefficient is available (Neset, 1984). For the mining method of longwall with controlled caving, the suggested range of extraction coefficient values is 0.85 to 0.95 . It is necessary to realise that the coefficient of extraction value expresses the ratio between the volume of the subsidence trough at the surface and the volume of extracted material. The general definition is independent of both the angle of the main influence and the mining depth. If the measured subsidence is known, the value of the coefficient can be approximately determined as a ratio of maximum subsidence to the mining height.

For example, if $a=0.95$, it is assumed that the volume of the subsidence trough formed will occupy $95 \%$ of the volume of extracted coal; the remaining $5 \%$ of this space will remain permanently in the rock mass (permanent bulking of the caving zone and stratification of the overlying layers). The percentage of the volume of extracted material that remains permanently in the rock mass depends not only on the character of the overburden rocks, but also on the degree of failure of rigid overlying strata caused by previous mining and, above all, on the depth of mining.

As the mining proceeds to a great depth, it is necessary to adjust the value of the mining coefficient against the specified value for the mining method (Jiránková, 2012). According to the mining experience in the OKC District, in light of the above, the coefficient of extraction for the first seam was initially chosen in the range $a=0.2$ to 0.3 , for the extraction of the second seam $a=0.4$ to 0.5 , and for the extraction of the third seam $a=0.6$ to 0.7 . For multiple mining at a depth of up to $700 \mathrm{~m}$, the coefficient of extraction was selected to range from 0.85 to 0.95 (Neset, 1984). For multiple mining at depths greater than $700 \mathrm{~m}$, the mining coefficient does not exceed 0.8 (Jiránková, 2012). However, for the mining of each underlying seam, it is necessary to add the so-called activation of the old workings from the previous mining in the overburden. It is practically impossible to determine the value of the surface subsidence caused by the activation of the old excavations without regular surface monitoring, performed during the entire mining period. Therefore, it is necessary to test and verify different methods of surface subsidence evaluation for the $\mathrm{OKC}$ conditions, to provide reliable predictions.

\subsubsection{EFFICIENCY COEFFICIENT}

The efficiency coefficient expresses the dependence of the surface points' movement on the goaf size. Its value depends on the distribution function choice and varies in the range from 0 to 1 . The efficiency coefficient is related to the radius of the main influence range, using the angle of main influence shown in Figure 1. The angle of main influence depends on the main influence angle of the particular rock mass layers and their thickness (Jiránková, 2010). The particular angles of influence for each bedding layer can be determined, either by 
physical modelling or by long-term monitoring of surface subsidence and assessing the range of the affected area in relation to the depth and extent of mining. In the Ostrava-Karvina Coalfield, the values of the main influence angle $(\beta)$ for the Carboniferous was $\beta_{2}=65^{\circ}$ and for the tertiary overburden $\beta_{1}=55^{\circ}$ was determined, based on long experience (Neset, 1984). In addition to the radius of the main influence range $(r)$, a suitable distribution function needs to be selected to calculate the efficiency coefficient value. In the $1960 \mathrm{~s}$, research was conducted to demonstrate the suitability of the Bals and Knothe distribution functions to calculate surface subsidence for the OKC District (Zenc, 1969).

Currently, for the OKC District, only the Knothe influence function method is used to determine the empirical surface subsidence (Knothe, 1984). The Knothe influence function is based on the similarity between the relationship of the surface points' subsidence and the position and extent of a horizontally-bedded, extracted deposit that corresponds to the Gauss law of random distribution. The basic precondition of the Knothe method is the acceptance of a normal distribution to represent the mining effects manifested by the vertical movement in the rock mass. The normal distribution can be solved in 3-dimensional space or a 2-dimensional plane. If the mining effects are solved in the 2-dimensional plane, the influence function according to Knothe (Knothe, 1984) is:

$f(x)=\frac{1}{r} e^{-\frac{\pi x^{2}}{r^{2}}}$

where $r$ is the radius of the main influence range.

The vertical displacements $\left(w_{r}\right)$ of any point located above the excavation boundary are expressed using the distribution function curve:

$w_{r}=w_{\max } \cdot \int_{0}^{+\infty} f(x) d x$

where $w_{\max }$ is the maximum vertical displacement of the surface point above the excavation. Its value is the product of the extracted thickness and the coefficient of extraction.

For empirical calculation, Knothe proposed the mining effects distribution inside the area of main influence as described in Figure 1. The maximum effect on the subsidence is the area extracted in the middle of the main influence range. This effect is shown as the peak of the Gaussian curve on the z-axis. With increasing distance from this peak (projected into the $\mathrm{x}, \mathrm{y}$ plane), the effect of the extracted area on the surface subsidence gradually decreases until the effect is zero at a distance corresponding to the maximum radius of the main influence range. This fact is taken into account when dividing the main influence range (excavation area) into zones with the same effect by concentric circles $r_{1}$ to $r_{5}$ (Fig. 1). The zones of same effect can be used to predict subsidence by the graphical method.

\subsubsection{TIME COEFFICIENT}

The first surface movement is shown in certain time after excavating a part of seam. Rock caving advances from the seam to the surface at a certain velocity that depends in particular on the physicalmechanical properties of the rocks in the overlying strata (the strength of rocks, stratification, occurrence of water, etc.). For predictive calculation of the dynamic surface subsidence value, the time functions were determined as described (Hu et al., 2015; Wang et al., 2018). The time coefficient expressed using Knothe time function (Knothe, 1953) is represented by:

$\varphi_{t}=1-e^{-c t}$

where $c$ is the Knothe time parameter.

In the OKC District, the first surface movements appear approximately 3 months after the mining begins and stabilise 3 to 5 years after mining ends. For predictive calculation of the maximum surface subsidence value, the time coefficient value of 1 is selected.

\subsection{SUBSIDENCE BY NUMERICAL MODELLING}

Phase2 software was used for numerical modelling of the subsidence. This is a versatile 2D elasto-plastic finite element stress analysis program for designing underground or surface excavations and their support systems. This software can also be used to predict surface subsidence, which is one component of the total displacements. The key issue in numerical modelling analysis is the choice of the physical model that enables rock mass yielding (Małkowski, 2015). The Mohr-Coulomb yielding criterion can reasonably predict the large strata deformations induced by coal- seam mining (Ghabraie et al., 2017). Phase2 provides several rock material models including the Mohr-Coulomb failure criterion. This subsidence prediction method is suitable for a bedded structure of rock mass and can provide a comprehensive analysis for complex geometries. The method has the additional advantage of enabling the analysis of individual mining stages. The FEM numerical model solutions are only approximations of the reality. The disadvantage is that the initial inaccuracies in calculating the subsidence in the lower beds can eventually affect the final surface subsidence results. It is therefore essential to have a lot of experience with the parameters used in the model, which are based on the local geological conditions and characteristics of the overlying strata.

\subsubsection{PARAMETERS OF THE NUMERICAL MODEL}

The complex 3-dimensional numerical models make it possible to estimate and predict the mining subsidence in less complicated conditions at shallow mining depths (Huang et al., 2017; Zhang et al., 2019). However, to predict the more complex conditions of multi-seam deposit mining, the 2-dimensional 


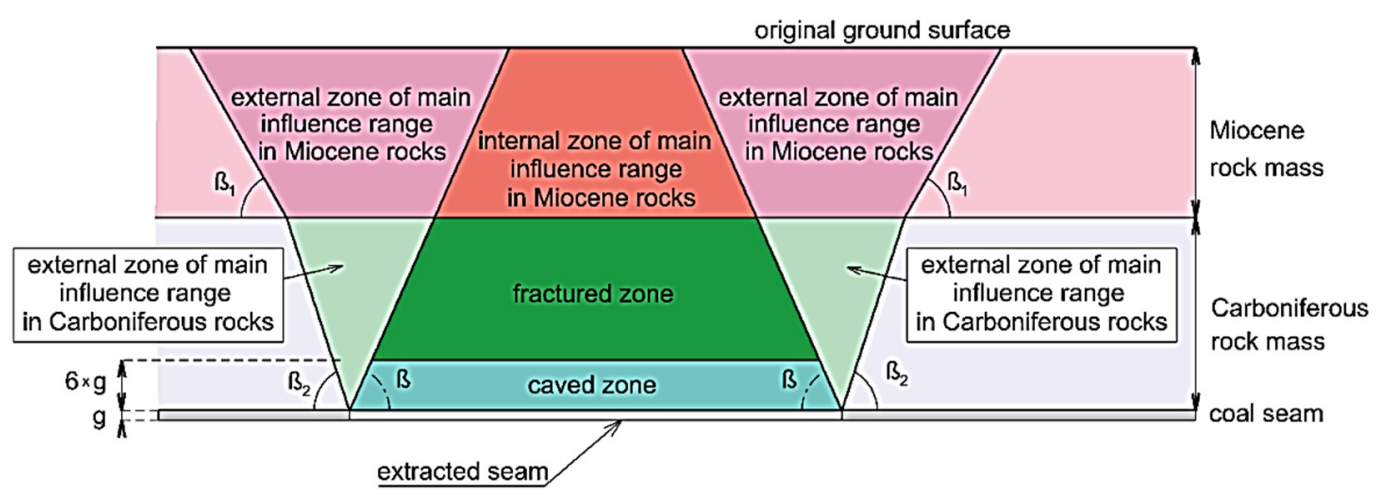

Fig. 5 Illustration of defined deformation zones for Carboniferous and Miocene overburden rocks in OKC mine

numerical models were used in this study. These numerical models provide a suitable and acceptable simplification of the 3D geomechanical geometries. Due to simplification, the rock mass was modelled as a stratum with unified properties. The numerical model presented here was calibrated using the measured subsidence. Considering the expected range of main influence and the site conditions within the studied area, a model of $800 \mathrm{~m}$ high and $1,540 \mathrm{~m}$ wide was developed for the study. The modelled mesh was refined into the structure boundaries (3-noded triangle mesh resolution from 2 to $32 \mathrm{~m}$ and the average side of the elements of approximately $12 \mathrm{~m}$ ). To ensure sufficient accuracy, this model includes more than 20,600 elements.

Use of the popular finite element method for estimating mining subsidence is not new (Zhu et al., 2018; Ju et al., 2019; Peng, 2008). The real goal is to implement the method in a practical manner, which is usable to predict subsidence due to mining at great depths. To achieve this, we have reformed the existing view of the zone formation in the overburden. The existing view is based on determining the overburden failure height, which consists of both the fractured zone height and the caving zone height. The height of the zones was thought to depend on the extracted seam thickness (Ju et al., 2019), however, this assumption is only suitable for mining at shallow depths of up to $200 \mathrm{~m}$. We found large differences between the measured and modelled subsidence when using the old method for mining at great depth (greater than $400 \mathrm{~m}$ ). Presented here is a new view on how to determine the overburden failure. The acceptable differences between the measured and modelled subsidence were detected when the fractured zone parameters were assigned for all seams in the Carboniferous rock mass in OKC mines. This procedure is used in this case study. We defined the range of the fractured zones using the angle of the main influence for Carboniferous rocks. The caving area was six times the extracted seam thickness in overburden, as is typical, based on experience in OKC mines (Konicek and Waclawik, 2018; Konicek et al., 2018). This experience related with the bulking factor of fallen rock which range 1.1 to 1.25 according to rock property. The value of 1.16 is used on the basis of long-term experience in OKC mines (Working rules, 2006). Using the angle of the main influence for both Carboniferous rocks and Miocene rocks, we defined the internal zone of the main influence range and the external zone of the main influence range, as shown in Figure 5.

\subsubsection{BOUNDARY CONDITIONS}

The modelled dimensions were chosen so that the boundary conditions did not affect the evaluated part of the modelled surface, defined by surface points 15 and 25. Therefore, the side areas of the model were selected at a distance greater than the range of the main influence. Boundary conditions allowing movement in all directions, with no constraint, were used for the free surface of the modelled area. The original ground surface represents the topography of the modelled area. Typical boundary conditions were chosen at the sides with vertical but no lateral movement, while the bottom of the model was fixed.

\subsubsection{OVERBURDEN PROPERTIES}

A series of numerical assessments of the failure of overlying strata enabled the relationship between the depth and goaf width to be derived for certain mechanical properties (Jiránková, 2012). When the failure of the overlying strata, fractured and caved zone develops, the fracture zones of previous mining operations interconnect. A proper understanding of the relationship between the thickness of the fracture zone and the mining depth is important for modelling surface subsidence, as well as determining the fractured and caved zone deformation parameters (see Table 2).

Commonly used values for the geomechanical properties of the rock mass in the OKC District (Konicek et al., 2019; Konicek et al., 2018) were applied in the model (see Table 2). The average values of the initial mechanical parameters were interpolated from the data obtained by almost 3,000 laboratory tests 
Table 2 Input data for the numerical model.

\begin{tabular}{|c|c|c|c|}
\hline Rock mass & $\begin{array}{c}\text { Elasticity modulus } \\
(\mathrm{MPa})\end{array}$ & Poisson's ratio & $\begin{array}{c}\text { Rock density } \\
\left(\mathrm{kg} / \mathrm{m}^{3}\right)\end{array}$ \\
\hline Carboniferous rock mass & 10,000 & 0.20 & 2,600 \\
\hline Miocene rock mass & 900 & 0.30 & 2,200 \\
\hline Seam & 800 & 0.30 & 1,300 \\
\hline Caved zone & 250 & 0.40 & 2,000 \\
\hline Fractured zone - Carboniferous & 250 & 0.40 & 2,000 \\
\hline Internal zone - Miocene & 300 & 0.30 & 2,200 \\
\hline External zone - Carboniferous & 900 & 0.35 & 2,600 \\
\hline External zone - Miocene & 500 & 0.30 & 2,200 \\
\hline Fault & 250 & 0.40 & 2,500 \\
\hline
\end{tabular}

Table 3 Compression strength values of individual lithological rock types in the OKC (Ptacek et al., 2017).

\begin{tabular}{lcc}
\hline Rock & $\begin{array}{c}\text { Compressive strength range (uniaxial } \\
\text { compression) } \\
(\mathrm{MPa})\end{array}$ & $\begin{array}{c}\text { Average value of } \\
\text { compressive strength } \\
(\mathrm{MPa})\end{array}$ \\
\hline Coal & $13.0-30.0$ & 21.9 \\
Mudstone & $33.0-123.0$ & 59.2 \\
Siltstone & $21.0-219.0$ & 90.3 \\
Fine-grained sandstone & $102.0-203.0$ & 123.8 \\
Medium-grained sandstone & $28.0-200.0$ & 73.5 \\
Coarse-grained sandstone & $37.0-140.0$ & 89.0 \\
Conglomerate & $54.0-163.0$ & 108.0 \\
\hline
\end{tabular}

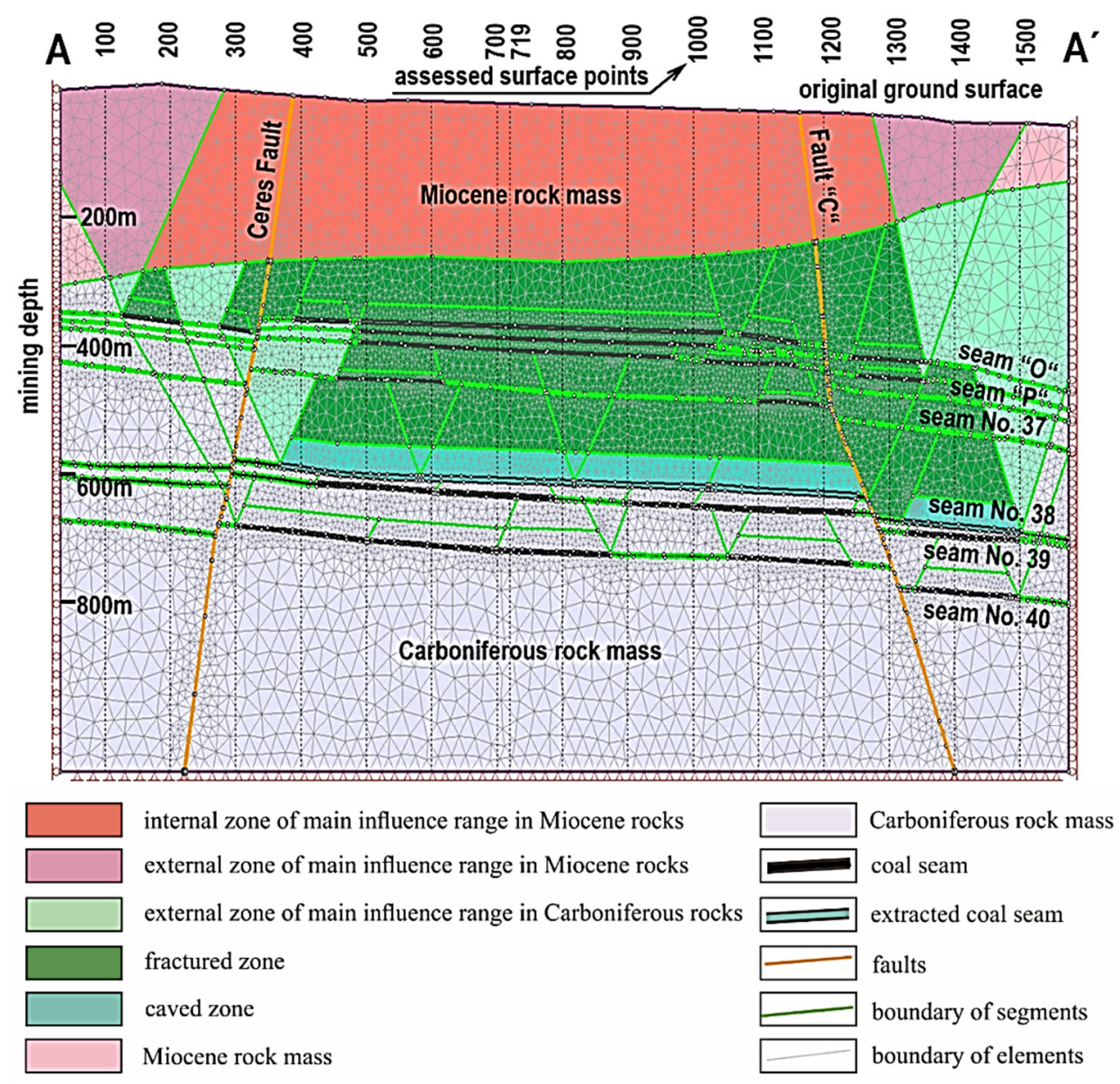

Fig. 6 Model section of the mining stage after mining the seam No. 38 (14th October 2003) with the same colour scheme describing the influence zones as labelled in the Figure 5. 


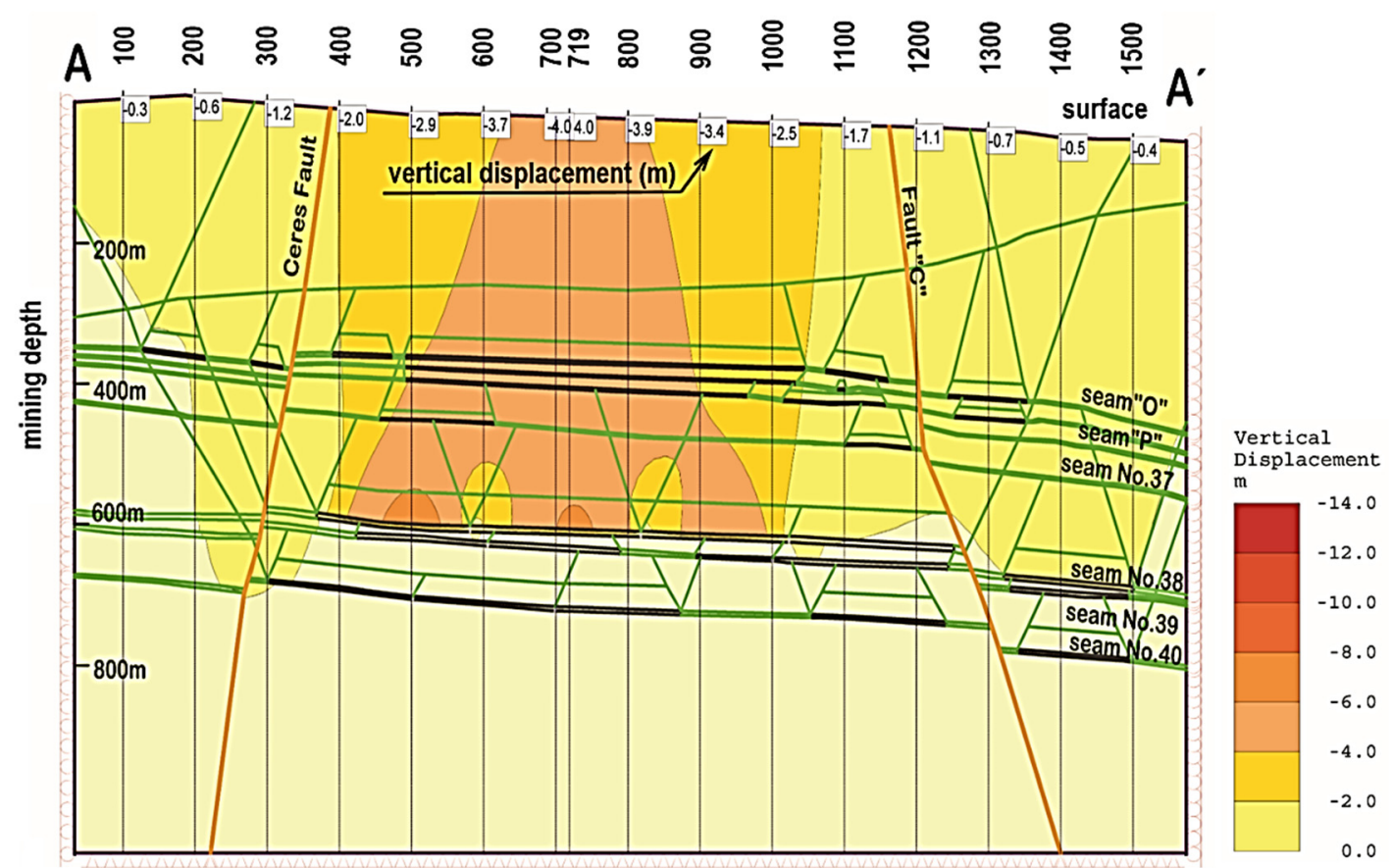

Fig. 7 Modelled vertical displacement distribution after mining the seam No. 38 (14th October 2003).

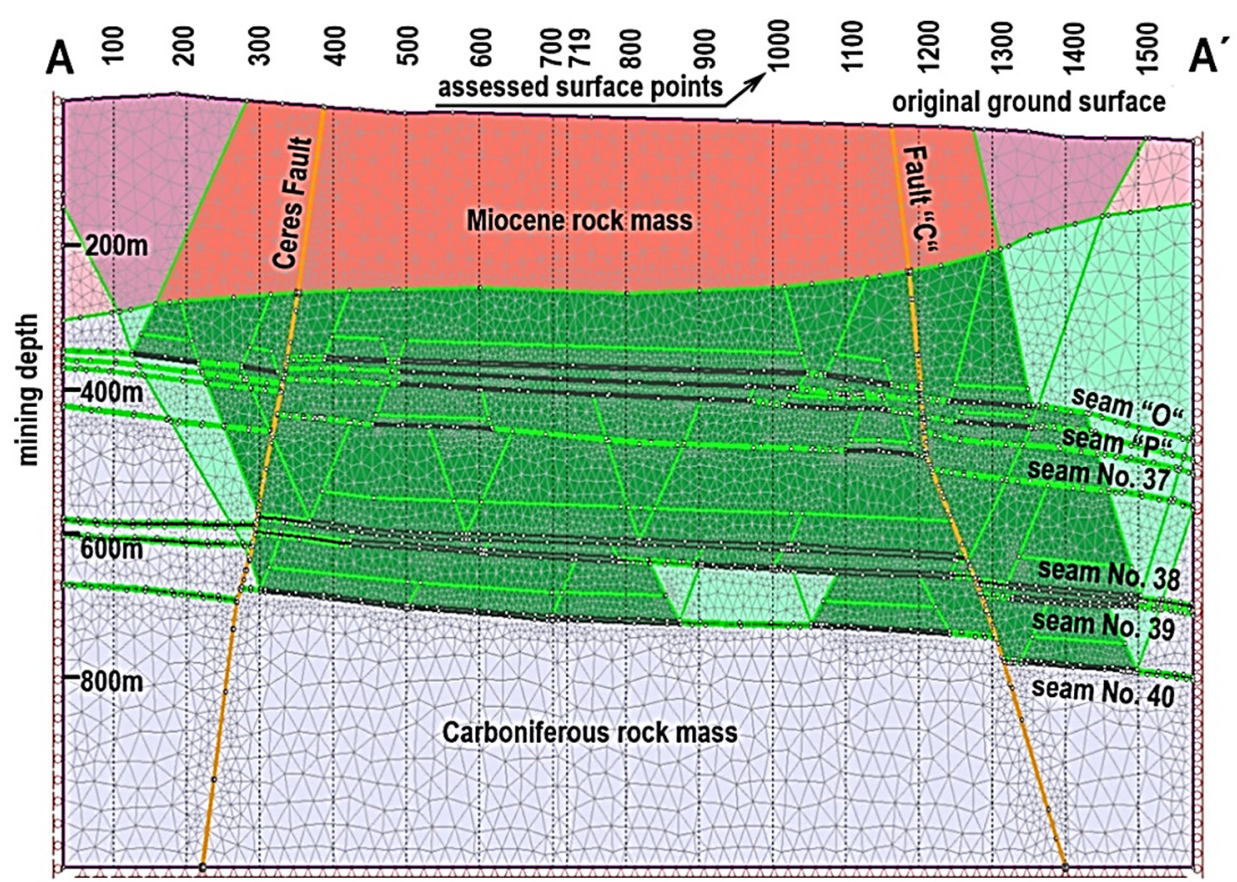

Fig. 8 Model section after mining was completed (24th October 2012) with the same colour scheme describing the influence zones as labelled in the Figure 5.

on intact rock samples (Ptacek et al., 2017), tested during the long history of mining in the area. The range of rock strengths within the same lithology is shown in the Table 3. Based on a number of experimental studies (Kulatilake et al., 2004; Mohammad et al., 1997), Young's modulus $(E)$ of the in situ rock masses ranged from $47 \%$ to $60 \%$ of the intact rock, and Poisson's ratio $(v)$ was approximately $115 \%$ of the intact rock. For this reason, E was reduced by $45 \%$ and $v$ was increased by $15 \%$, in this study.

The geometry of the numerical model and vertical displacement distribution in the modelling stage before mining of seam 39 are shown in Figures 6 and 7. The numerical model geometry and vertical displacement distribution in the last modelling stage after mining of seams 38,39 and 40 are shown in Figures 8 and 9. 


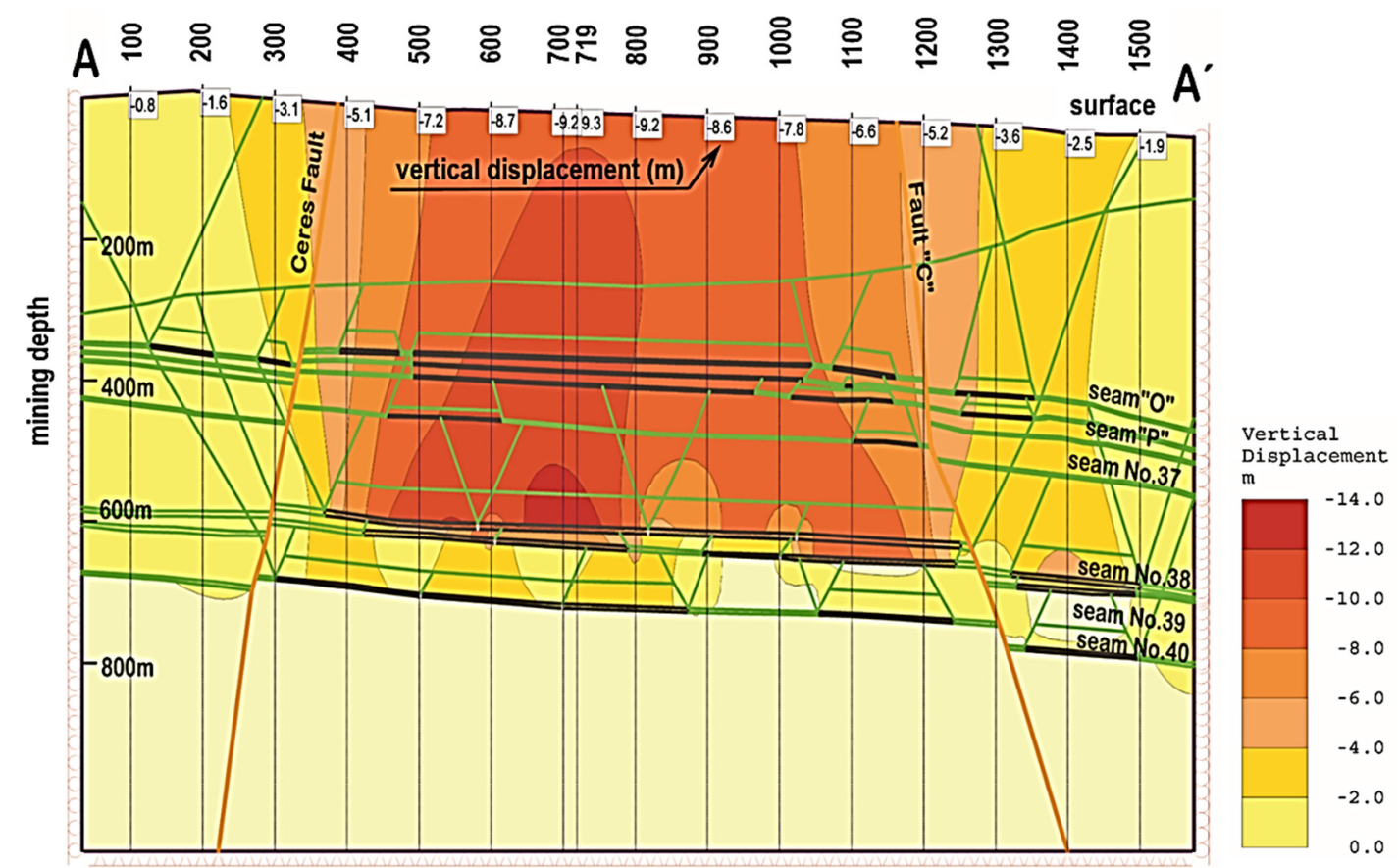

Fig. 9 Final vertical displacement distribution after completion of mining (24th October 2012).

surface points

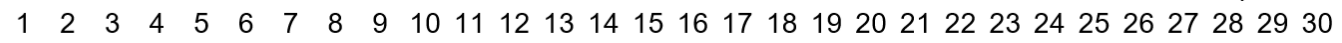

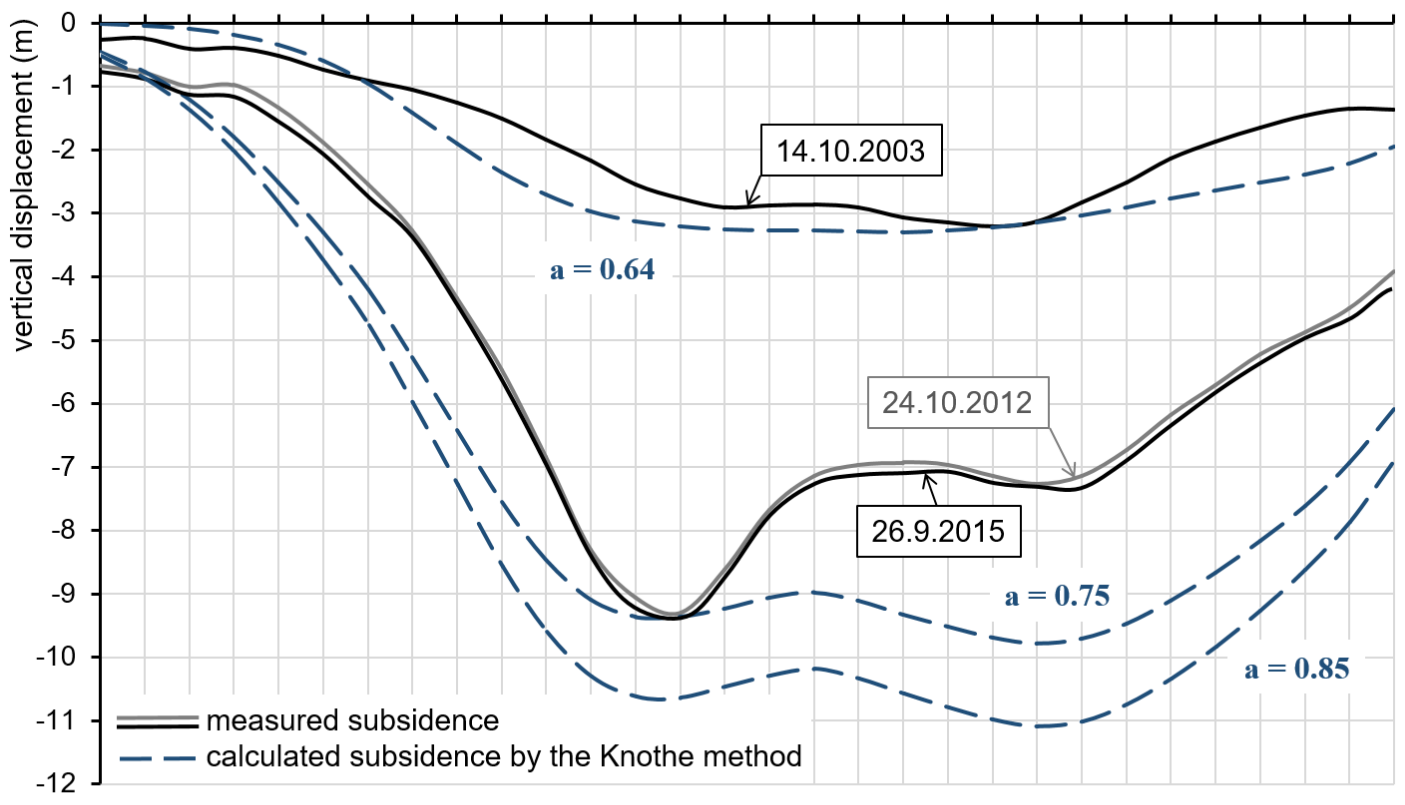

THE LONGWALL MINING IN THE SEAMS AND THE MINING LOCATION BELOW THE SURFACE POINTS

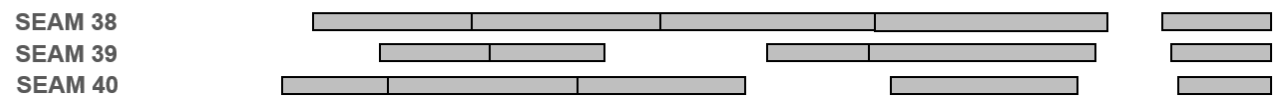

Fig. 10 Measured and empirical subsidence along the line of surface points.

The model section shows all longwall mining in the evaluated area (Figs. 6 -9) in order to determine the extent of zones (internal and external zones of main influence range). The numerical calculation of the vertical displacements has been started for the panels which mined-out from the date of the first surface survey (on 19.10.1998).

\section{RESULTS}

\subsection{COMPARISON BETWEEN MEASURED AND EMPIRICAL SUBSIDENCE}

The empirical subsidence calculations were carried out using software based on the Knothe method. All longwall panels (seams 38, 39 and 40) were included in the empirical subsidence 
calculations. The value of the extraction coefficient was chosen such that both the measured and empirical subsidence coincided at the largest measured subsidence value. The largest subsidence value of $3.202 \mathrm{~m}$ was measured on 14.10.2003 at surface point 21. This measured subsidence value corresponded to the empirical subsidence when the value of the extraction coefficient $a=0.64$ was used. After surface subsidence stabilised, the largest subsidence value of $9.394 \mathrm{~m}$ was measured on 26.9.2015 at surface point 14. The largest measured subsidence value corresponded to the empirical subsidence when the value of the extraction coefficient $a=0.75$ was used. However, in the case of predictive calculations, the measured values of the surface subsidence are unknown. As mentioned in Section 3.1.1, for the mining technology of controlled caving, the range of extraction coefficient from 0.85 to 0.95 was determined. The extraction coefficient value $a=0.85$ for the empirical subsidence curve was also used to show the maximum difference of $1.3 \mathrm{~m}$ between the modelled subsidence values, as shown in Figure 10. Below the graph, the undermining of the surface points by longwall mining in seams 38,39 and 40 are shown.

The results of the measured subsidence on 24.10.2012 and 26.9.2015 prove that the surface subsidence stabilised after mining ended. The subsidence increase during the period from 24.10.2012 to 26.9.2015, ranging from $80 \mathrm{~mm}$ to $250 \mathrm{~mm}$. Extraction all panels in the seams 38, 39 and 40 of the $9^{\text {th }}$ mining block ended on 1.2.2013. The last small longwall panel $908-2$ in the seam 40 was extracted during the period from 24.10.2012 to 1.2.2013. Since the last longwall excavation area was very small, the measured subsidence during this period was minor. The results of the measurement correspond to the experience in the OKC District, where surface subsidence stabilisation occurred within a period of 3 years.

The differences in both slopes of the subsidence trough are perceptible from the comparison of measured and empirical values, as shown in Figure 10. The varying character of rigid overburden failure is the cause of these differences, corresponding to the experience at other locations in the OKC District. The rigid layers overlying the borders of the stope are stressed only in the elastic strain, whereas the rigid layers above the goaf were disturbed by brittle deformation. Another difference between the expected and the real shape of the subsidence trough is in the position of the point of greatest subsidence. Whereas the subsidence trough which formed on the surface had the greatest subsidence at surface point 14 of $8.741 \mathrm{~m}$, in the empirical calculation (using the extraction coefficient value $a=0.75$ ), the greatest subsidence was determined at surface point 22 with a value of $9.78 \mathrm{~m}$. The identified differences between reality and the empirical assumptions, which have been described in this paper, can be summed up as having two main causes. The first is the fact that the empirical assumptions were formulated and verified at the time when mining took place at smaller depths than at the present time. The second is the generalisation itself of the empirical assumptions and their uniform use for the inhomogeneous environment of the rock mass in different parts of the OKC District, even though in reality the natural conditions of each site are unique. The empirical subsidence model requires a great simplification of the rock conditions and does not allow either the rock mass inhomogeneity or the occurrence of tectonic failures to be taken into account. These reasons lead us to model surface subsidence using FEM.

\subsection{COMPARISON BETWEEN MODELS AND SUBSIDENCE MEASUREMENTS}

The measured surface subsidence values include cumulative vertical displacement changes, induced by mining of seams 38, 39 and 40, as well as activation of the old overlying mined-out seams. The model section line $\mathrm{A}-\mathrm{A}^{\prime}$ passes through the surface points 15 and 25 (Fig. 2). The surface subsidence of points between relative chainages of 100 to $1500 \mathrm{~m}$ are determined by interpreting the directly measured subsidence along the surface line 1-30 and radar interferometry results (Lazecký and Jiránková, 2013; Lazecký et al., 2017). The possibility uses of the satellite radar interferometry are mentioned in the publications (Blachowski et al., 2018; Jirankova and Lazecky, 2016).

The empirical subsidence of the points in the model section line were calculated by the Knothe method, using an extraction coefficient $\mathrm{a}=0.85$ for the survey at 14.10.2003 and at 26.9.2015, as shown Figure 11. When comparing the subsidence at 14.10 .2003 , i.e. after the mining of the longwall panels in seam 38 and before mining seams 39 and 40, a difference of $1.4 \mathrm{~m}$ between the measured and calculated subsidence occurred at chainage $719 \mathrm{~m}$. The difference at 26.9 .2015 , i.e. after the mining of the panels in seams 38,39 and 40, occurred with a value of $1.6 \mathrm{~m}$. The value of the difference between measured and calculated subsidence was changed for greater mining depths from $1.4 \mathrm{~m}$ (for an average mining depth of $619 \mathrm{~m}$ ) to $1.6 \mathrm{~m}$ (for an average mining depth of $694 \mathrm{~m}$ ) at chainage $719 \mathrm{~m}$, i.e. the position of the greatest observed subsidence in the $\mathrm{A}-\mathrm{A}^{\prime}$ line. When comparing the measured subsidence and the results of the numerical modelling on 14.10.2003, the difference of $1.1 \mathrm{~m}$ occurred at chainage $719 \mathrm{~m}$. The difference on 26.9.2015, occurred with a value of $0.5 \mathrm{~m}$. The value of the difference between the measured and model subsidence was changed for greater mining depths from $1.1 \mathrm{~m}$ (for an average mining depth of $619 \mathrm{~m}$ ) to $0.5 \mathrm{~m}$ (for an average mining depth of $694 \mathrm{~m}$ ) at chainage $719 \mathrm{~m}$. The input data used in the models are interpreted data, while the measured subsidence values are directly observed and, therefore, suitable for validation of the models. The comparison between 


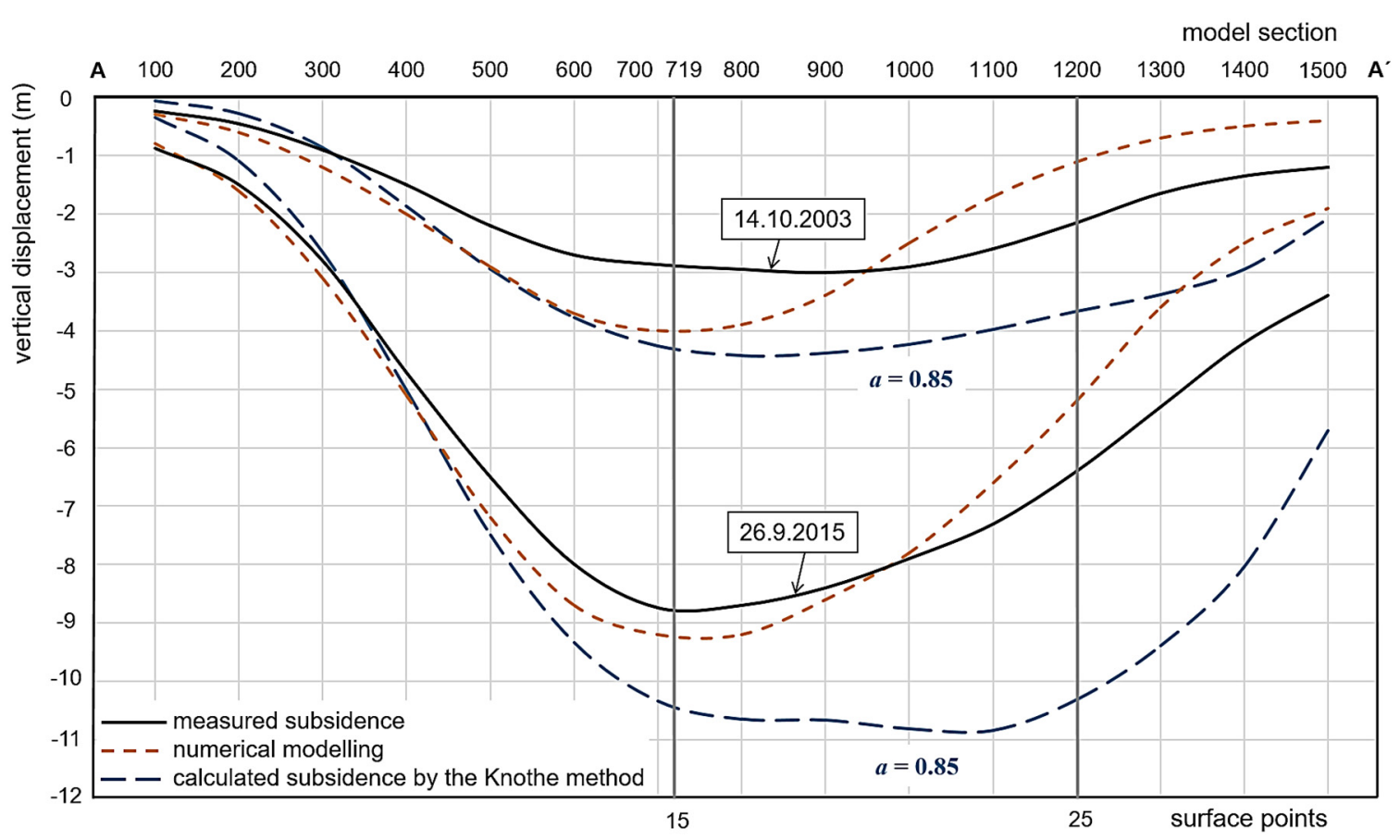

Fig. 11 Models and measured subsidence at the section A-A'.

the models and measured subsidence indicates that the FEM result differs by $5.7 \%$ from the measured value and the Knothe method result differs by $18.4 \%$ from the measured value for greater mining depth.

When comparing the subsidence at 14.10.2003 in the right part of the profiles, the difference of $1.5 \mathrm{~m}$ between measured and empirical subsidence occurred at chainage $1200 \mathrm{~m}$. The difference on 26.9.2015, occurred with a value of $3.9 \mathrm{~m}$. When comparing the measured subsidence and the results of the numerical modelling at 14.10.2003, the difference of $-1.0 \mathrm{~m}$ occurred at chainage $1200 \mathrm{~m}$. The difference between measured subsidence and result of the numerical modelling at 26.9.2015 occurred with a value of $-1.2 \mathrm{~m}$ at this chainage. The subsidence by FEM method differs by $48.6 \%$ from the measured value for an average mining depth of $619 \mathrm{~m}$ and differs by $18.7 \%$ from the measured value for an average mining depth of $694 \mathrm{~m}$. The subsidence by using the Knothe method differs by $72.2 \%$ from the measured value for an average mining depth of $619 \mathrm{~m}$ and by $60.9 \%$ from the measured value for an average mining depth of $694 \mathrm{~m}$.

To explain the reason why the empirical subsidence was larger than the measurements in the right part of the profiles, consider the following arguments: 1) Is the surface subsidence in multiple seam mining algebraically cumulative (Peng, 2015)? 2) How does the shape and range of excavations affect the surface subsidence? The first question points to the contradiction between the empirical subsidence and the measured surface subsidence in multiple seam mining. The empirical subsidence is calculated as being algebraically cumulative but, in fact, due to multiple seam mining, the interaction exists between the seams and the overburden, which produces the surface subsidence. In terms of the shape and range of the excavation, the effects on the surface subsidence are evident, as shown Figure 2. Although panel 906 has the longest length, it occurs in a location where the most coal pillars affect the overburden failure. In addition, Fault " $\mathrm{C}$ " affects the right side of the profiles, although it cannot be included in the empirical subsidence calculation. All of these reasons contribute to the differences between the empirical and measured subsidence seen at the right side of the profile.

\section{DISCUSSION}

The rock mass represents a nonlinear and nonhomogeneous environment. Therefore, methods for both the modelling and prediction of subsidence present a very difficult task. Both the FEM and the Knothe modelling methods showed some differences when compared to the observed subsidence. The FEM method cannot be exact as it is impossible and unrealistic to provide precise rock mass properties. This was attempted through the proposed new arrangement of the overburden zones. The deformation part of the rock mass was divided into external and internal zones using the angle of the main influence. The outcome of this study indicates that the FEM method is practical and applicable for predicting surface subsidence in mining at great depths. The Knothe subsidence prediction method has the limitations mentioned above. With this in mind, a procedure has been proposed to adjust the value of the extraction coefficient in the Knothe's method for greater mining depths. 


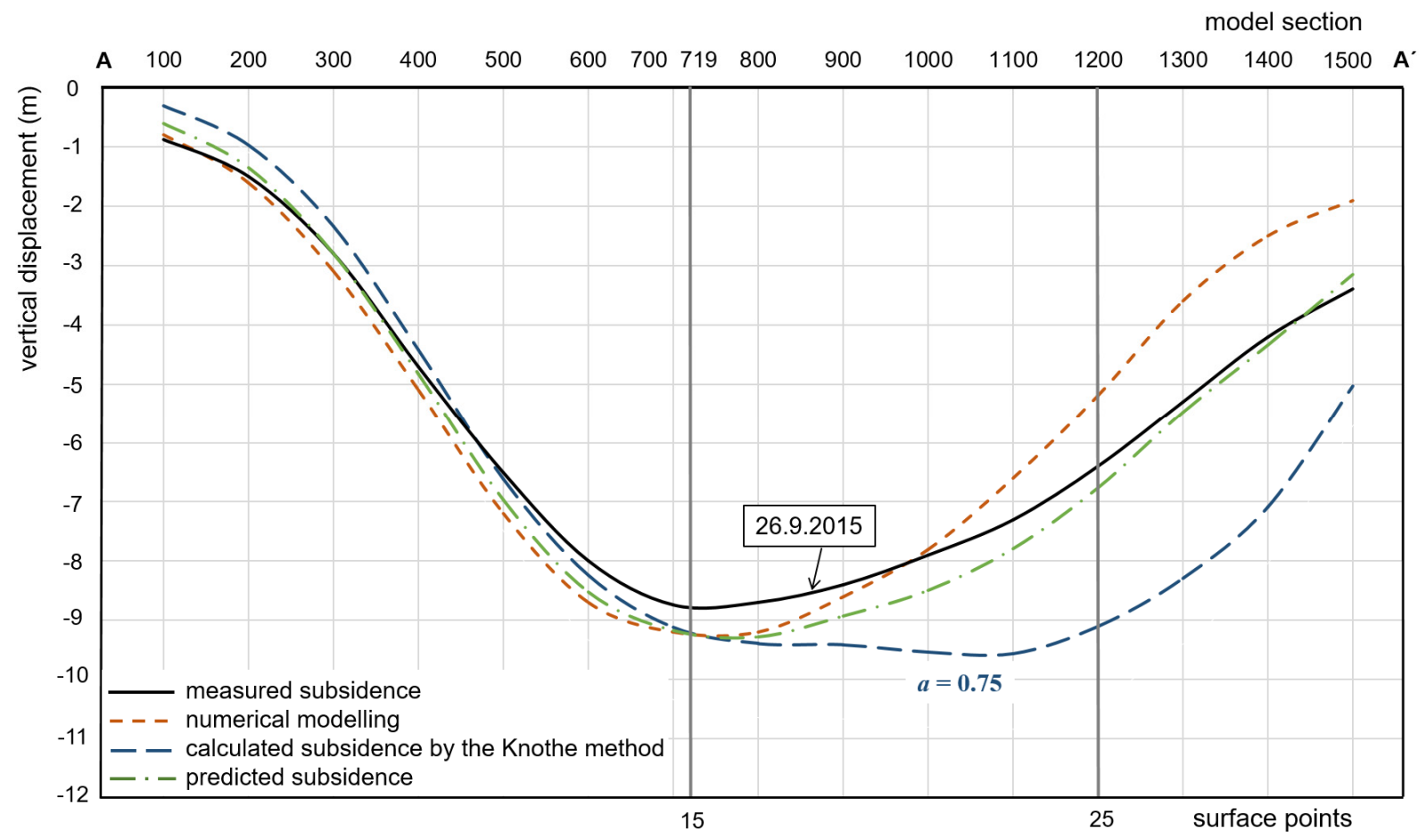

Fig. 12 Models, measured and predicted subsidence at the line model section A-A'.

The main task of the prediction is to determine the surface subsidence before mining, i.e. when the observed subsidence is unknown and cannot be used to validate the Knothe model, as shown in Section 4.1. We do not reject either method but propose the following procedure to predict surface subsidence at greater mining depths.

Step 1: Processing a 2D numerical model in a section line passing through the centre of the planned excavation.

Step 2: Determining the extraction coefficient value from the greatest subsidence, which appears in the numerical model, and then using it for the Knothe subsidence prediction method.

Step 3: Modelling the surface subsidence prediction on the slope of the subsidence trough by using the results of both methods.

The above procedure was demonstrated in this case study. The predicted subsidence was determined using the weighted average, as shown in Figure 12. When comparing the measured subsidence and the results of the numerical modelling at 26.9.2015, the difference of $0.5 \mathrm{~m}$ occurred at chainage $719 \mathrm{~m}$. The difference at 26.9.2015, occurred with a value of $-1.2 \mathrm{~m}$ at chainage $1200 \mathrm{~m}$. The subsidence determined by the FEM method differs by $18.7 \%$ from the measured value for average mining depth of $694 \mathrm{~m}$. The results were used to determine the extraction coefficient $a=0.75$ for the Knothe subsidence prediction method, with the difference of $2.7 \mathrm{~m}$ from the measured value at 26.9.2015 at chainage $1200 \mathrm{~m}$. The value of the extraction coefficient was chosen such that both the numerical model and calculated subsidence by the Knothe method coincided at the largest numerical model subsidence value. When this was used $(a=0.75)$, the result of the subsidence calculated by the Knothe method differed by $42.1 \%$ from the measured value (for $\mathrm{a}=0.85$, this value was $60.9 \%$ ) at chainage $1200 \mathrm{~m}$. The last step is to predict surface subsidence. The weight of these numerical model results was larger than the weight of the Knothe model results because the Knothe model was determined using the adjusted value of the extraction coefficient from the numerical model results. It was found that the weight of the numerical model results should be in the range from one third to a half greater than the weight of the Knothe model results. The predicted value differs from the measured value by $8 \%$ at a point $719 \mathrm{~m}$ along the $\mathrm{A}-\mathrm{A}^{\prime}$ section. The slope of the predicted subsidence trough was within the range of 2 to $8 \%$ from the surveyed subsidence. At the point numbered $1200 \mathrm{~m}$, the predicted value was within $5 \%$ of the measured value.

\section{CONCLUSIONS}

The empirical methods of predicting surface subsidence become less reliable when the mining advances to great depths. This case study presents a new perspective on the practical application of both FEM and Knothe methods, when mining at great depths (greater than $400 \mathrm{~m}$ ). In practice, the Knothe method is still used and is popular for its simplicity, but it cannot use the complex conditions of the rock 
mass. The FEM method can use the rock mass properties but some simplifications of rock mass conditions are necessary.

In this case study, a procedure was proposed, to reduce the differences between the measured and the predicted surface subsidence. The observed subsidence was used for validation of both the FEM and Knothe modelling methods. The subsidence from the FEM method differs by $18.7 \%$ from the measured value and the subsidence by the Knothe method differs by $60.9 \%$ from the measured value for an average mining depth of $694 \mathrm{~m}$, in the slope of the predicted subsidence trough. The results from the FEM method were used to determine the extraction coefficient $\mathrm{a}=0.75$ for the Knothe subsidence prediction method. The subsidence calculated by the Knothe method differed by $42.1 \%$ from the measured value. The predicted subsidence was determined using both methods, with the result differing by $5 \%$ from the measured value.

\section{ACKNOWLEDGMENTS}

This article was supported by a project for the long-term conceptual development of research organizations (RVO: 68145535).

\section{REFERENCES}

Blachowski, J., Jirankova, E., Lazecky, M., Kadlečík, P. and Milczarek, W.: 2018, Application of satellite radar interferometry (PSInSAR) in analysis of secondary surface deformations in mining areas. Case studies from Czech Republic and Poland. Acta Geodyn. Geomater., 15, No. 2, 173-185. DOI: 10.13168/AGG.2018.0013

Cui, X., Li, C., Hu, Q. and Miao, X.: 2013, Prediction of surface subsidence due to underground mining based on the zenith angle. Int. J. Rock Mech. Min. Sci., 60, 246-252. DOI: 10.1016/j.ijrmms.2012.12.036

Ghabraie, B., Ghabraie, K., Ren, G. and Smith, J.V.: 2017, Numerical modelling of multistage caving processes: insights from multi-seam longwall mining-induced subsidence. Int. J. Numer. Anal. Methods Geomech., 41, 959-975. DOI: 10.1002/nag.2659

Hu, Q., Deng, X., Feng, R., Li, Ch., Wang, X. and Jiang, T.: 2015, Model for calculating the parameter of the Knothe time function based on angle of full subsidence. Int. J. Rock Mech. Min. Sci., 78, 19-26. DOI: 10.1016/j.ijrmms.2015.04.022

Huang, G., Kulatilake, P.H.S.W., Shreedharan, S., Cai, S. and Song, H.: 2017, 3-D discontinuum numerical EFRENCES of subsidence incorporating ore extraction and backfilling operations in an underground iron mine in China. Int. J. Min. Sci. Technol., 27, No. 2, 191-201. DOI: $10.1016 /$ j.ijmst.2017.01.015

Jiang, Y., Misa, R., Tajduś, K., Sroka, A. and Jiang, Y.: 2020, A new prediction model of surface subsidence with Cauchy distribution in the coal mine of thick topsoil condition. Arch. Min. Sci., 65, 1, 147-158. DOI: $10.24425 / \mathrm{ams} .2020 .132712$

Jiránková, E.: 2010, Assessment of rigid overlying strata failure in face mining. Cent. Eur. J. Geosci., 2, No. 4, 1-7. DOI: $10.2478 / \mathrm{v} 10085-010-0014-7$
Jiránková, E.: 2012, Utilisation of surface subsidence measurements in assessing failures of rigid strata overlying extracted coal seams. Int. J. Rock Mech. Min. Sci., 53, 111-119. DOI: $10.1016 /$ j.ijrmms.2012.05.007

Jirankova, E., Lazecky, M.: 2016, Specifics in the formation of subsidence troughs in the Karvina part of the Ostrava-Karvina Coalfield with the use of radar interferometry. Acta Geodyn. Geomater., 13, No. 3, 263-269. DOI: 10.13168/AGG.2016.0008

Jiránková, E., Petroš, V. and Šancer, J.: 2012, The assessment of stress in an exploited rock mass based on the disturbance of the rigid overlying strata. Int. J. Rock Mech. Min. Sci., 50, 77-82.

DOI: 10.1016/j.ijrmms.2012.01.004

Ju, Y., Wang, Y., Su, C., Zhang, D. and Ren, Z.: 2019 , Numerical analysis of the dynamic evolution of mining-induced stresses and fractures in multilayered rock strata using continuum-based discrete element methods. Int. J. Rock Mech. Min. Sci., 113, 191-210. DOI: 10.1016/j.ijrmms.2018.11.014

Knothe, S.: 1953, Effect of time on formation of basin subsidence. Archives of Mining and Steel Industry, 1, $1-7$.

Knothe, S.: 1984, Prediction of the mining influence. Katowice, Wyd. „Sląsk”, 159 pp, (in Polish).

Konicek, P., Ptacek, J., Waclawik, P. and Kajzar, V.: 2018, Long-term Czech experiences with rockbursts with applicability to today's underground coal mines. Rock Mech. Rock Eng., 52, 1447-1458. DOI: $10.1007 /$ s00603-018-1489-y

Konicek, P., Schreiber, J. and Nazarova, L.: 2019, Volumetric changes in focal areas of seismic events correspond to destress blasting. Int. J. Min. Sci. Technol., 29, No. 4, 541-547. DOI: $10.1016 / j$. .jmst.2019.06.004

Konicek, P., Soucek, K., Stas, L. and Singh, R.: 2013, Longhole destress blasting for rockburst control during deep underground coal mining. Int. J. Rock Mech. Min. Sci., 61, 141-153.

DOI: 10.1016/j.jirmms.2013.02.001

Konicek, P. and Waclawik, P.: 2018, Stress changes and seismicity monitoring of hard coal longwall mining in high rockburst risk areas. Tunn. Undergr. Space Technol., 81, 237-251. DOI: $10.1016 /$ j.tust.2018.07.019

Kulatilake, P.H.S.W., Park, J. and Um, J.: 2004, Estimation of rock mass strength and deformability in 3-D for a $30 \mathrm{~m}$ cube at a depth of $485 \mathrm{~m}$ at Äspö Hard Rock Laboratory. Geotech. Geol. Eng., 22, No. 313, 313330. DOI: 10.1023/B:GEGE.0000025033.21994.c0

Lazecký, M.and Jiránková, E.: 2013, Optimization of satellite INSAR techniques for monitoring of subsidence in the surroundings of Karviná mine: Lazy plant. Acta Geodyn. Geomater., 10, No. 1, 61-65. DOI: 10.13168/AGG.2013.0005

Lazecký, M., Jiránková, E. and Kadlečík, P.: 2017, Multitemporal monitoring of Karvina subsidence troughs using SENTINEL-1 and TERRASAR-X interferometry. Acta Geodyn. Geomater., 14, No. 1, 53-59. DOI: 10.13168/AGG.2016.0027

Małkowski, P.: 2015, The impact of the physical model selection and rock mass stratification on the results of numerical calculations of the state of rock mass 
deformation around the roadways. Tunn. Undergr. Space Technol., 50, 365-375.

DOI: 10.1016/j.tust.2015.08.004

Mohammad, N., Reddish, D. and Stace, L.R.: 1997, The relation between in situ and laboratory rock properties used in numerical modelling. Int. J. Rock Mech. Min. Sci., 34, No. 2, 289-297.

DOI: $10.1016 / \mathrm{S} 0148-9062(96) 00060-5$

Neset, K.: 1984, Effects of undermining. Prague, 340 pp, (in Czech).

Peng, S.S.: 2008, Coal mine ground control. 3rd ed., Dept. of Mining Engineering/College of Engineering and Mineral Resources, Morgantown, $750 \mathrm{pp}$.

Peng, S.S.: 2015, Topical areas of research needs in ground control - A state of the art review on coal mine ground control. Int. J. Min. Sci. Technol., 25, No. 1, 1-6. DOI: $10.1016 /$ j.ijmst.2014.12.006

Ptacek, J., Konicek, P., Holecko, J., Przeczek, A., Waclawik, P., Pavelek, Z., Macura, M., Kajzar, V. and Kukutsch, R.: 2017, Rockbursts in Ostrava-Karvina Coalfield. Ostrava: Institute of Geonics of the Czech Academy of Sciences, $147 \mathrm{pp}$.

Ren, G. and Li, J.: 2008, A study of angle of draw in mining subsidence using numerical modeling techniques. Electron. J. Geotech. Eng., 13, 1-14. http://www.ejge.com/2008/Ppr0883.pdf

Sroka, A., Knothe, S., Tajduś, K. and Misa, R.: 2015, Point movement trace vs. the range of mining exploitation effects in the rock mass. Arch. Min. Sci., 60, No. 4, 921-929. DOI: 10.1515/amsc-2015-0060

Tajduś, K.: 2009, New method for determining the elastic parameters of rock mass layers in the region of underground mining influence. Int. J. Rock Mech. Min. Sci., 46, No. 8, 1296-1305.

DOI: $10.1016 /$ j.ijrmms.2009.04.006
Tajduś, K., Misa, R. and Sroka, A.: 2018, Analysis of the surface horizontal displacement changes due to longwall panel advance. Int. J. Rock Mech. Min. Sci., 104, 119-125. DOI: 10.1016/j.ijrmms.2018.02.005

Tichavský, R., Jiránková, E. and Fabiánová, A.: 2020, Dating of mining-induced subsidence based on a combination of dendrogeomorphic methods and in situ monitoring. Eng. Geol., 272, 105650. DOI: $10.1016 /$ j.enggeo.2020.105650

Wang, B., Xu, J. and Xuan, D.: 2018, Time function model of dynamic surface subsidence assessment of groutinjected overburden of a coal mine. Int. J. Rock Mech. Min. Sci., 104, 1-8. DOI: $10.1016 /$ j.ijrmms.2018.01.044

Working rules to Regulation No. 659/2004, 2006. Coll. of the Czech Mining Office, Paskov, (in Czech).

Zenc, M.: 1969, Comparison of Bals's and Knothe's methods of calculating surface movements due to underground mining. Int. J. Rock Mech. Min. Sci. Geomech. Abstr., 6, No. 2, 159-190. DOI: 10.1016/0148-9062(69)90033-3

Zhang, B., Ye, J., Zhang, Z., Xu, L. and Xu, N.: 2019, A comprehensive method for subsidence prediction on two-seam longwall mining. Energies, 12, 16, No. 3139, 1-14. DOI: 10.3390/en12163139

Zhu, W., Yu, S. and Xu, J.: 2018, Influence of the elastic dilatation of mining-Induced unloading rock mass on the development of bed separation. Energies, 11, 4, No. 785, 1-16. DOI: 10.3390/en11040785 